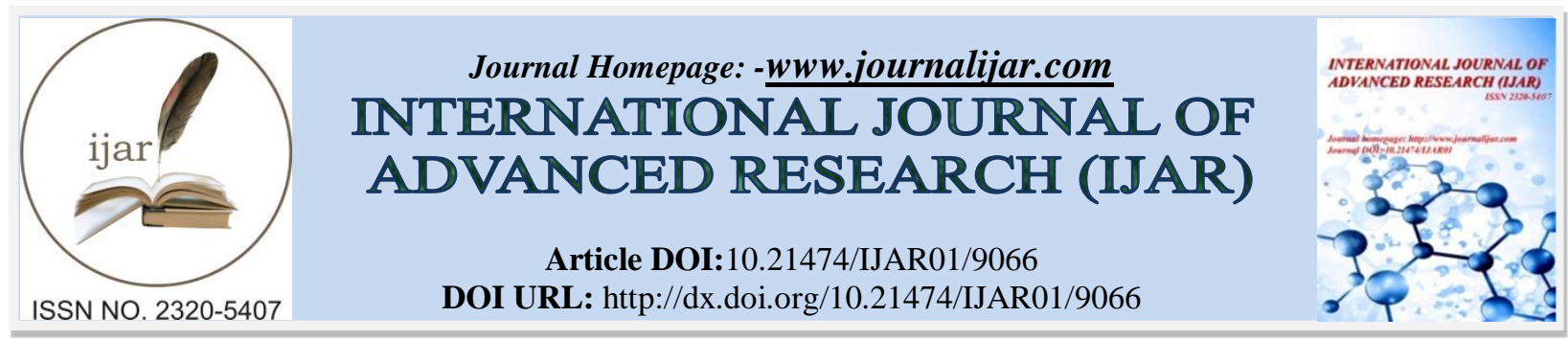

RESEARCH ARTICLE

\title{
ANIMALS AS WEATHER-FORECASTING BIO-INDICATORS A CASE STUDY OF DIFFERENT COMMUNITIES OF BISHNUPUR DISTRICT, MANIPUR, NE INDIA."
}

\author{
Th. Ajita Chanu', Robindro Teron ${ }^{1}$, O. Shashi Kumar Singh ${ }^{2}$ And H. Tombi Singh ${ }^{1}$.
}

1. Department of Life Sciences \& Bioinformatics, Assam University, Diphu Campus.

2. Department of Zoology, D. M. College of Science, Imphal, Manipur.

\section{Manuscript Info}

Manuscript History

Received: 14 March 2019

Final Accepted: 16 April 2019

Published: May 2019

Key words:-

Bioindicators, Bishnupur, Traditional

knowledge, Forecasting \& bicultural diversity.

\begin{abstract}
The indigenous people of Manipur, particularly those confined in Bishnupur district, have vast applications of traditional knowledge predicting the weather forecast using bioindicators based on the behaviour of animals. The bioindicators are mainly based on the behavioral of animals. The use of bioindicators is an innovative approach for assessing various types of environmental mismanagement, including pollution, high input farming, inappropriate disposal of wastes, contamination, etc. The successful applications of the forecasting knowledge are based on comparison with past events, good prognosis, close observation and a thorough understanding of the local environment. Local community members, cultural leaders and local elders have observed recent abnomalies in the weather, with unusual rains and abrupt changes in temperature. Due to this phenomenon, some plant species are changing their growth patterns. This type of traditional knowledge has excellent for wider application, in Bishnupur as elsewhere; there is a threat to people's livelihoods and cultural diversity. Today, there is an urgent need to document all traditional knowledge and folklore among the diverse ethnic communities before the traditional cultures are completely lost.
\end{abstract}

Copy Right, IJAR, 2019,. All rights reserved.

\section{Introduction:-}

Traditional knowledge is very important which is mainly based on innovations and practices of indigenous local communities following traditional lifestyles. Ethnic and local people, especially farmers, fishers, hunters and local medicine practitioners are very astute weather-watchers and are quick to recognize weather conditions and whether they are not favorable to their production systems. Traditional practices wisdom developed over many generations of holistic traditional utilization of the lands, natural resources and environment. This knowledge is generally passed down from generation to generations by experiential learning and word of mouth and is importantly most part, undocumented in written form.

Bishnupur district lies in the south-western corner of the Manipur Valley (also known as Imphal Valley). The district, covering a total area of $530 \mathrm{~km}$ and stretching from $93.43^{\circ} \mathrm{E}$ to $93.53^{0} \mathrm{E}$ longitude $24.18^{0} \mathrm{~N}$ and $24.44^{0} \mathrm{~N}$ latitudes, is located at the South Western Part of the valley region of Manipur State. It is situated at an altitude of $800 \mathrm{~m}$ amsl. 
Historically and culturally, Bishnupur district is an important place in Manipur as the district with a number of traditional stories, historical events and monuments.

The ethnic people, especially farmers and fishers, are very incisive weather watchers and are quick to recognize weather conditions and whether or not they are favorable to their production systems (Posey D,1992; Mcfarland et.al.,1994 ; Lantz TC et.al.,2003; Ravi Shankar et.al., 2008). The production and application of local forecasts are deeply localized, derived from an intimate interaction with a micro environment whose rhythms are interwined with the cycles of seasonal changes. The vulnerability caused by vagaries of the weather creates a knowledge base among the ethnic people/farmers in the form of Indigenous Technical Knowledge (ITK) that helps people to overcome uncertainty and prepare for possible adverse or favorable events (Posey D, 1992; Altieri, M,1999 ; Roncoli C et.al.,2002).

Local indicators and local knowledge systems cannot be replaced with scientific knowledge, because they are holistic and specific to local situations, providing farmers and others with the ability to make decisions and prepare for the coming agricultural year (Posey D,1992;Bharara LP et.al., 1994;Altieri M, 1999 ; Ravi Shankar et.al., 2008; Sandeep Acharya,2011).

Scientific evidence of climate variability of events such as droughts and floods suggests that climatic oscillations have occurred in the past and may occur in future, potentially with larger impacts on human society and economy and on the ecosystems on which they depend (Bharara LP, 1986 ; Fisher, 1997; Aparna P et.al.,2011). There is an evidence to show that slow and gradual climatic changes over the earth's history have been interspersed with abrupt climatic changes such as rapid cooling, warming, wetting and drying due to the forcing of earth systems across the threshold (Bharara L.P, 1986; Aparna P et.al.,2011).

Despite the presence of modern technology to predict weather conditions over the next day or month in a specific location, folk weather lore has remained an important form of local weather forecasting, and can serve to supplement public meteorological information and weather prediction. People have been attempting to predict the weather for a very long time and have used a number of different methods, some of which have proven very effective and successful (Sandeep Acharya,2011; Angchok D et.al.,2006; Galacgac ES et.al., 2009). There is an urgent need to authenticate the various traditional methods of weather prediction, especially rainfall forecasting, and ways to predict other natural weather phenomena such as floods, cyclones, etc(Sandeep Acharya,2011; Angchok D et.al.,2006).

Indigenous knowledge is now much sought after in the present context of globalization. However, while the diverse knowledge systems of the third world are claimed as heritage that belongs to all humanity, the knowledge about how to apply this diversity is often exclusive to the domain of the people who have developed it (Hussain Z,1991; Balwanera P, 2001; Aparna P et.al.,2011).

\section{Materials and methods:-}

The aim of the present study is to document the traditional indigenous knowledge of some indicator species used for weather forecasting and assessing climate change, in order to assist cultural preservation and renewal among different communities of Bishnupur district of Manipur, especially the Meiteis, Kabuis, Koms and Chothes, etc. The study is mainly based on the data collected from the primary sources, interviews and group discussions with local elders and personal interactions with villagers of Bishnupur District, Manipur.

Respondents who had lived in the village for the past many years and preferably older than 30 years were mainly targeted. Interviews of the selected respondents were conducted in their homes using open ended questionnaires. This gave the respondents an opportunity to describe important features of their local weather forecast systems while detailing features that are important for them. Information on demographic characteristics and indigenous knowledge of forecasting the onset of the rainy seasons was collected.

Although investigation and data collection was a tedious one because the indigenous people are hesitant to transfer their traditional knowledge acquired from their ancestors since time immemorial, there was no literature and no well documented data in the study area before. The participant's observations were also used in data collection. Questionnaires made to different group of elders were a checklist that included issues on conventional climate 
forecast knowledge, seasonal rainfall predictions, knowledge on traditional indicators and past climatic events documented through interviews.

Most of the people interviewed in this study valued traditional knowledge in relation to early warning and copying mechanisms for natural disasters. Only a few self-confident young people who were accustomed to the use of transport vehicles said that they rely mainly on radio weather forecasts rather than on local methods of anticipating weather events.

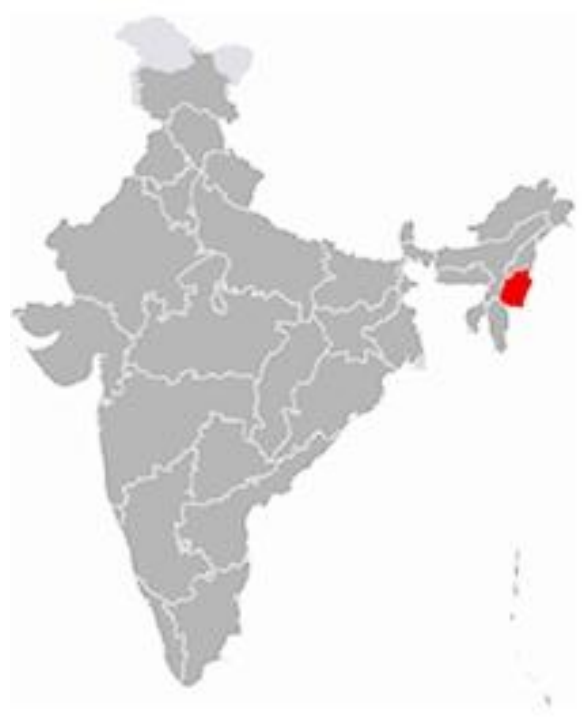

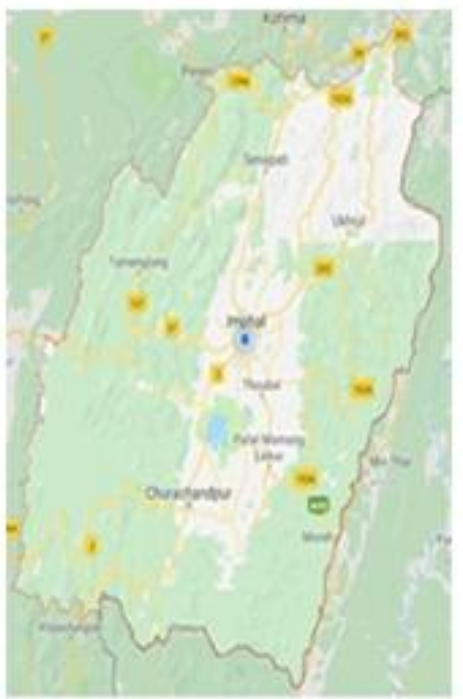

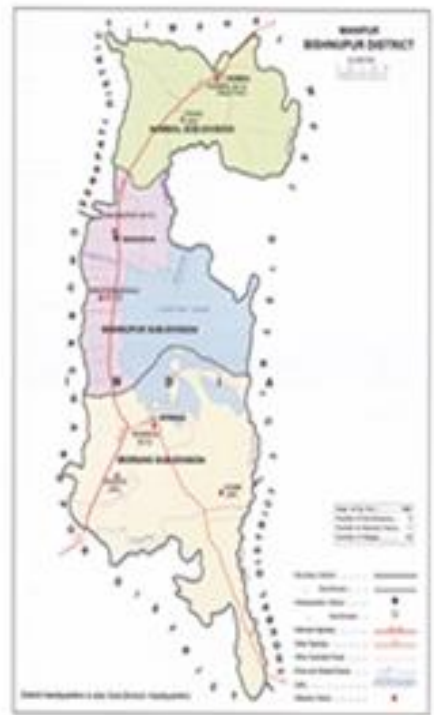

Fig 1:-Bishnupur District, Manipur.

\section{Results:-}

The present investigations reveals the use of 28 species of animals belonging to 27 genera and 25 families as Animal Indicator species for prediction of weather conditions by the different indigenous ethnic communities of Bishnupur District, Manipur, belonging to the Meiteis, Meitei Pangals (Muslims), certain tribes, viz. Chothe, Kabui and Kom tribes. These ethnic people mostly relied on similar bioindicators to predict rainfall and other weather conditions. The study revealed that indigenous knowledge systems have enabled the various ethnic communities in the area to live in harmony with their environments for generations, and that their traditional knowledge systems are important tools in environmental conservation and natural disaster management. Based on this traditional knowledge and people's long standing experiences concerning cloud formation, lightning wind directions, occurrence of rains in a particular period of the lunar calendar, the indigenous rain forecasters predict the reasonably exact nature of rainfall for the entire season, including good and undesired effects (e.g., flooding, droughts).

In traditional weather forecasting, the onset of the rainy season and upcoming rain is also indicated by the unusual behavior of certain birds and animal's aggressive and abnormal activities. The possibility and beginning of the rainy season in Bishnupur is signaled by the unusually chirping of the Apis dorsata Fabricius, Bos taurus Linnaeus, Bufo melanostictus Schneider, Centropus toulou bengalensis Gmelin, Cuculus canorus Linnaeus, Megalaima asiatica, Megalaima australis Cyanotis Melanochlora sultanea Hodgson, Odontotermes sp., Papilio Linnaeus, , Picus canus Gmelin, Pycnonotus jocosus Linnaeus and Treron cuvirostra nipalensis. In traditional weather forecasting, a typhoon or flood is imminent when insects start incessant chirping Pheretima posthuma (earthworm), coming out of the ground and scattered in the backyard of the houses, Rucervus eldii eldii (deer) become restless and also spiders spin shorter and thicker webs (Sivanarayana G,1993; Seetharaman RN, 2001; Angchok D et.al.,2006; Galacgac ES et.al.,2009; Sandeep Acharya,2011).

These findings on traditional bioindicators of weather uses of 28 (twenty eight) animals used by ethnic communities of Bishnupur district of Manipur, N.E. India are shown in Table 1 below: 
Table1:-Indicator species of animals for prediction of weather conditions

\begin{tabular}{|c|c|c|c|c|c|}
\hline Sl.no & Scientific name & Family & $\begin{array}{l}\text { Common } \\
\text { name/Local name }\end{array}$ & $\begin{array}{l}\text { Animal } \\
\text { biological } \\
\text { behaviour }\end{array}$ & Weather predictions \\
\hline 1 & $\begin{array}{ll}\text { Acridotheres } & \text { fuscus } \\
\text { Wagler } 1827 & \end{array}$ & Sturnidae & $\begin{array}{l}\text { The Northern } \\
\text { Jungle Myna/ } \\
\text { Chonga amubi. }\end{array}$ & $\begin{array}{l}\text { Call of Chonga } \\
\text { amubi }\end{array}$ & Summer season. \\
\hline 2 & $\begin{array}{l}\text { Apis dorsata } \\
\text { Fabricius, } 1793\end{array}$ & Apidae & $\begin{array}{l}\text { Honey bee / } \\
\text { Khoiren }\end{array}$ & $\begin{array}{l}\text { Wasps hiding } \\
\text { their honeycomb }\end{array}$ & Upcoming rain \\
\hline 3 & $\begin{array}{l}\text { Apis mellifera } \\
\text { Linnaeus, } 1758\end{array}$ & Apidae & Honey bee & $\begin{array}{l}\text { Appearance and } \\
\text { movement of the } \\
\text { insect. }\end{array}$ & Onset of dry season \\
\hline 4 & $\begin{array}{l}\text { Araneus angulatus } \\
\text { Clerck, } 1757\end{array}$ & Araneidae & Spider/ Mirang & $\begin{array}{lr}\text { Spider } & \text { spinning } \\
\text { shorter } & \text { and } \\
\text { producing } & \text { thicker } \\
\text { web } & \end{array}$ & $\begin{array}{lr}\text { Adverse } & \text { weather } \\
\text { condition } & \text { (typhoon } \\
\text { or flood). } & \end{array}$ \\
\hline 5 & $\begin{array}{l}\text { Bos Taurus Linnaeus, } \\
1758\end{array}$ & Bovidae & Cow/San & $\begin{array}{l}\text { Calves becoming } \\
\text { uneasy }\end{array}$ & Upcoming rain \\
\hline 6 & $\begin{array}{l}\text { Bubulcus ibis } \\
\text { coromandus Boddart, } \\
1783\end{array}$ & Ardeidae & $\begin{array}{l}\text { The Cattle Egret/ } \\
\text { Sandungil }\end{array}$ & $\begin{array}{l}\text { Appearance of } \\
\text { migratory the } \\
\text { Cattle Egret }\end{array}$ & Onset of dry season \\
\hline 7 & $\begin{array}{l}\text { Bufo melanostictus } \\
\text { Schneider } 1799\end{array}$ & Bufonidae & Frog / Hangoi & $\begin{array}{l}\text { Croaking of toad/ } \\
\text { frog }\end{array}$ & Possibility of rain. \\
\hline 8 & $\begin{array}{ll}\text { Centropus } & \text { toulou } \\
\text { Gmelin } 1788 & \\
\end{array}$ & Cuculidae & $\begin{array}{l}\text { The Lesser } \\
\text { Coucal /Nongoubi }\end{array}$ & Call of Nongoubi & Possibility of rain. \\
\hline 9 & $\begin{array}{l}\text { Cicada sp. Linnaeus, } \\
1758\end{array}$ & Cicadidae & $\begin{array}{l}\text { Cicada/Hari } \\
\text { nongnang }\end{array}$ & $\begin{array}{l}\text { Chirping of } \\
\text { insect (Cicada) }\end{array}$ & $\begin{array}{l}\text { End of a day ( } \\
\text { approaching dusk) }\end{array}$ \\
\hline 10 & $\begin{array}{l}\text { Corvus } \\
\text { macrorhynchos } \\
\text { levaillantii Lesson } \\
1831\end{array}$ & Corvidae & $\begin{array}{lr}\text { The } & \text { Eastern } \\
\text { Jungle } & \text { Crow/ } \\
\text { Kwak } & \end{array}$ & $\begin{array}{l}\text { Crows nesting at } \\
\text { low height of } \\
\text { trees. }\end{array}$ & Windy year. \\
\hline 11 & $\begin{array}{l}\text { Cuculus canorus } \\
\text { Linnaeus, } 1758\end{array}$ & Cuculidae & Common cuckoo & Calling of cuckoo & Upcoming rain \\
\hline 12 & $\begin{array}{l}\text { Formica sp. } \\
\text { Linnaeus, } 1758 \\
\end{array}$ & Formicidae & Ant/Kakcheng & $\begin{array}{l}\text { Ants carrying } \\
\text { their eggs }\end{array}$ & Occurrence of flood. \\
\hline 13 & $\begin{array}{l}\text { Gallus gallus } \\
\text { (Linnaeus, 1758) }\end{array}$ & Phasianidae & $\begin{array}{l}\text { Red jungle fowl / } \\
\text { Lamyel }\end{array}$ & $\begin{array}{l}\text { Unusual clucks } \\
\text { and sand bathing }\end{array}$ & Occurrence of flood \\
\hline 14 & $\begin{array}{l}\text { Gracula religiosa } \\
\text { Linnaeus, } 1758\end{array}$ & Sturnidae & $\begin{array}{l}\text { Northern Hill } \\
\text { Myna / Chong- } \\
\text { nga amubi }\end{array}$ & $\begin{array}{l}\text { Unusual chirping } \\
\text { and aggressive } \\
\text { behaviour }\end{array}$ & Occurrence of flood \\
\hline 15 & $\begin{array}{l}\text { Halcyon symensis } \\
\text { Swainson, } 1821\end{array}$ & Alcedinidae & $\begin{array}{l}\text { The Eastern } \\
\text { White breasted } \\
\text { Kingfisher/ } \\
\text { Ngarakpi }\end{array}$ & $\begin{array}{l}\text { Appearance of } \\
\text { Ngarakpi }\end{array}$ & Winter season \\
\hline 16 & $\begin{array}{l}\text { Lonchura striata } \\
\text { Linnaeus, } 1766\end{array}$ & Estrildidae & $\begin{array}{l}\text { White-rumped } \\
\text { munia / Ushuk }\end{array}$ & $\begin{array}{l}\text { Chirping } \\
\text { unusually with } \\
\text { strident sound }\end{array}$ & $\begin{array}{l}\text { Adverse weather } \\
\text { condition }\end{array}$ \\
\hline 17 & $\begin{array}{l}\text { Megalaima asiatica } \\
\text { Latham, } 1790\end{array}$ & Megalaimidae & $\begin{array}{l}\text { The Blue } \\
\text { Throated Barbel / } \\
\text { Hungkrok laobi }\end{array}$ & Unusual chirping & Upcoming rain \\
\hline 18 & $\begin{array}{l}\text { Megalaima australis } \\
\text { Cyanotis Blyth } 1847\end{array}$ & Megalaimidae & $\begin{array}{l}\text { The Indian Blue- } \\
\text { eared Barbet / } \\
\text { Hangkrok laobi }\end{array}$ & $\begin{array}{l}\text { Unusual chirping } \\
\text { and flying low }\end{array}$ & Upcoming rain \\
\hline
\end{tabular}




\begin{tabular}{|c|c|c|c|c|c|}
\hline 19 & $\begin{array}{l}\text { Melanochlora } \\
\text { sultanea Hodgson, } \\
1837\end{array}$ & Paridae & Sultan Tit & Unusual chirping & Upcoming rain \\
\hline 20 & $\begin{array}{l}\text { Notonecta } s p . \\
\text { Linnaeus, } 1758\end{array}$ & Notonectidae & $\begin{array}{l}\text { Backswimmer } \\
\text { /Longkhajing }\end{array}$ & $\begin{array}{l}\text { Nesting above } \\
\text { the water level }\end{array}$ & Occurrence of flood. \\
\hline 21 & $\begin{array}{l}\text { Odontotermes } s p . \\
\text { Holmgren, } 1913\end{array}$ & Termitidae & $\begin{array}{l}\text { Termite /Leisou in } \\
\text { immature form, } \\
\begin{array}{l}\text { Mukthrubi in } \\
\text { winged form }\end{array}\end{array}$ & $\begin{array}{l}\text { Appearance of } \\
\text { many termites } \\
\text { indicates near } \\
\text { rainfall onset. }\end{array}$ & Upcoming rain \\
\hline 22 & $\begin{array}{l}\text { Papilio } \\
\text { Linnaeus, } 1758\end{array}$ & Papilionidae & Butterfly/Kurak & $\begin{array}{l}\text { Appearance of } \\
\text { many butterflies }\end{array}$ & Upcoming rain \\
\hline 23 & $\begin{array}{l}\text { Pheretima posthuma } \\
\text { Kinberg, } 1867\end{array}$ & Megascolecidae & $\begin{array}{l}\text { Earthworm/ } \\
\text { Tinthrok }\end{array}$ & $\begin{array}{l}\text { Earthworm } \\
\text { coming out from } \\
\text { the ground }\end{array}$ & $\begin{array}{ll}\text { Adverse } & \text { weather } \\
\text { condition (flood or } \\
\text { typhoon). }\end{array}$ \\
\hline 24 & $\begin{array}{l}\text { Picus canus } \\
\text { Gmelin, } 1788\end{array}$ & Picidae & $\begin{array}{l}\text { Grey headed } \\
\text { Woodpecker / } \\
\text { Ootubi }\end{array}$ & $\begin{array}{l}\text { Unusual activity } \\
\text { with rotation } \\
\text { around the tree }\end{array}$ & Upcoming rain \\
\hline 25 & $\begin{array}{l}\text { Pycnonotus jocosus } \\
\text { Linnaeus, } 1758\end{array}$ & Pycnonotidae & $\begin{array}{ll}\text { Red- } \quad \text { whiskered } \\
\text { Bulbul/ Khoining }\end{array}$ & Unusual chirping & Upcoming rain \\
\hline 26 & $\begin{array}{l}\text { Rucervus eldii eldii } \\
\text { M'Clelland, } 1842\end{array}$ & Cervidae & Deer /Sangai & $\begin{array}{l}\text { Deer becoming } \\
\text { restless }\end{array}$ & $\begin{array}{l}\text { Adverse weather } \\
\text { condition (flood or } \\
\text { typhoon). }\end{array}$ \\
\hline 27 & $\begin{array}{l}\text { Streptopelia } \\
\text { chinensis Scopoli, } \\
1768\end{array}$ & Columbidae & $\begin{array}{l}\text { Spotted dove } \\
\text { Leima khunu }\end{array}$ & $\begin{array}{l}\text { Chirping } \\
\text { unusually and } \\
\text { Moving in pairs } \\
\text { and taking shelter } \\
\text { in shadow of } \\
\text { leaves and }\end{array}$ & $\begin{array}{l}\text { Adverse weather } \\
\text { condition (flood or } \\
\text { typhoon). }\end{array}$ \\
\hline 28 & $\begin{array}{l}\text { Treron cuvirostra } \\
\text { nipalensis Gmelin, } \\
1789\end{array}$ & Columbidae & $\begin{array}{l}\text { Thickbilled Green } \\
\text { Pigeon / Khunu } \\
\text { ashangba }\end{array}$ & $\begin{array}{l}\text { Chirping } \\
\text { unusually }\end{array}$ & Upcoming rain \\
\hline
\end{tabular}
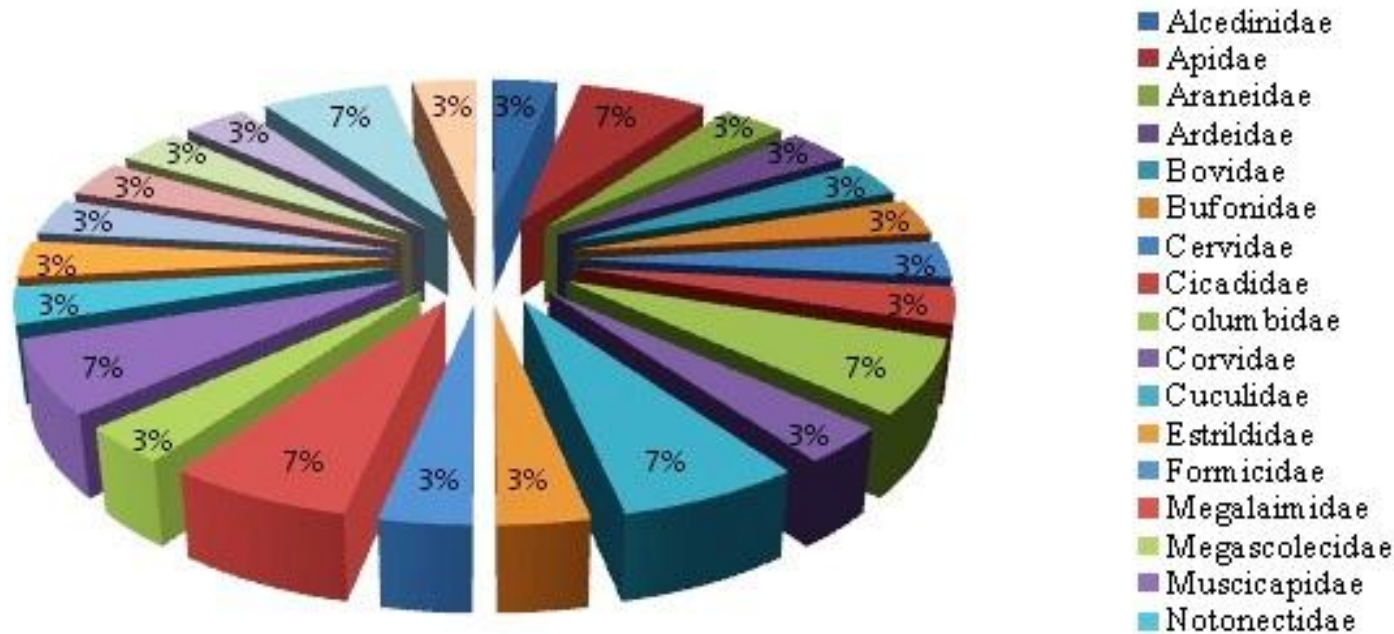

Fig 2:-Familywise distribution of indicator species of animals for prediction of weather conditions of Bishnupur district of Manipur 


\section{Discussion:-}

The behaviour of animals and the appearance and movement of birds and insects are frequently used by elders to predict weather and climate in their communities (Chang'a LB et.al.,1991). Local indicators were used by local communities in seasonal rainfall prediction. There have been interesting proposals about the validity of some animal folklore and it is pointed out that science is based on observation and folklore is based on centuries of observation although the observations were not conducted in controlled circumstances. Also, differences exist across species and between individuals of the same species in their sensitivity to weather fluctuations. While some animals may be great weather predictors, others within that same species might not show the same sensitivity (Hussain Z, 1991). Indigenous people expresses that when average number of cows are lying down in a field, rain is on its way as the cows sense the moisture in the air and are making sure they have somewhere dry to lie down. If average numbers stand up in their fields or pastures weather will be fine on the other hand, if they lie down in average, they sense the moisture of approaching rain and make sure they have a dry patch to lie on ${ }^{9}$. In Germany as a weather forecaster the green frog called Laubfrosch (in German language) is very popular for accurate prediction of weather condition( Angchok D et.al.,2006).Since indigenous knowledge is mainly based on relative experience and local experience, lack of benchmark makes it difficult to be harmonized and integrated into conventional forecasting system. Systematic documentation, quantification and subsequent integration of indigenous knowledge into conventional weather forecasting system is therefore recommended as one of the strategy that could help to improve the accuracy and reliability of seasonal forecasting information under a changing climate(Aparna P et.al.,2011).

\section{Conclusion:-}

Traditional indigenous knowledge deals with the activity of species at those very moments when animals prepare to take necessary precautions against upcoming natural dangers. Cultural emphasis on the relationship between knowledge and responsibility also calls for scientists to be more aware of and accountable for the intended and unintended impacts of scientific products. This is proven by substantial evidence from bioindicators (Table1) from India with a possible explanation for abrupt changes in behavioral activities of animals respectively. A number of literatures sources also support this evidence (Selvanayagum M,1991; Sen S, 1992; Altieri M, 1999; Balwanera P, 2001; . Laishram Imoba et.al.,2003; Turner NJ, 2003; Vavrova M,2003; Briggs John,2005; Dessai S et.al., 2005; Dekens Julie,2007; Turner N J,2006 \& 2009; Matari ER et.al.,2008; Joshua S et.al.,2013;). Now is the time to integrate data from modern techniques of weather forecasting from traditional indigenous knowledge, to support the extra demands for local weather prediction at specific times and in particular regions at this era of rapid climate change. If it is not done, countries like India, which are totally dependent on the seasonal rainfall for sustainable agricultural and allied activities, will suffer greatly in near future from deficiencies in short, medium and long range rain forecasting (State of Environment Report,Manipur(Turner N J et.al.,2006; State of Environment Report Manipur, 2009).

\section{Acknowledgement:-}

The authors express gratitude and thankfulness to the Department of Biotechnology, Ministry of Science and Technology, Government of India, New Delhi for providing the necessary financial support in carrying out field works for collection of materials and information required for the present investigations, and also for providing laboratory and computer facilities in the Bioinformatics Infrastructure Facility Centre in D. M. College of Science, Imphal, which was necessary for carrying out the present work. he Author is also thankful to Dr. Robindra Teron (Supervisor) and Dr. O. Shashi Kumar Singh( Co-Supervisor) for their eminent guidance in the preparation of this research paper.

Authors are further thankful to the ethnic people residing in different parts of Bishnupur District who shared their traditional knowledge with the authors and provided the useful information necessary for this article. Authors are thankful also to the local guides for their assistance, cooperation and hospitality during the field studies. 


\section{References:-}

1. Altieri, M. (1999). The Ecological Role of Biodiversity in Agroecosystems. Agric. Ecosyst. Environ. 74 (1-3), $19-31$.

2. Anandraja N, Rathakrishnan T, Ramasubramanian M, Saravan P \& Suganthi NS (2008). Indigenous weather and forecast practices of Coimbatore district farmers of Tamil Nadu, Indian J Traditional Knowledge. 7: 630633.

3. Angchok D \& Dubey VK (2006). Traditional method of rainfall prediction through Almanacs in Ladakh, Indian J Traditional Knowledge, 5(1) 145-150.

4. Aparna P \& PC Trivedi (2011). Cultural values and indigenous knowledge of climatic and disaster prediction in Rajasthan, India.

5. Antweiler C (1998). Local knowledge and local knowing: An anthropological analysis of contested cultural products in the context of development. Anthropos 93:469-494.

6. Balwanera P (2001). Conserving biodiversity and ecosystem services, Science,291(2047-204.

7. Bharara LP (1986). Indigenous Knowledge -A Copying Mechanism in Drought-prone Areas, and Changes and Consequences of Accelerating Risks and Vulnerability to Desertification in Western Rajasthan, Paper presented at Seminar on control of Drought, Desertification and Famine, New Delhi, Mimeo.

8. Bharara LP \& Seeland K. (1994). Indigenous Knowledge and drought in the arid zone of Rajasthan: weather prediction as a means to cope with a hazardous climate. Int Asienforum $25,53-71$.

9. Bhowmik, S. R. (from June 29th to july 1st,2010). Climate change and Indigenous peoples: Community adaptation and sustainbility of biocultural diversityin eastern Himalaya,Arunachal pradesh in 2010 Climate change adaptation conference: . Climate adaptation futures, preparing forunavoidable impacts of climate change , Gold Cost Queensland, Australia, 300.

10. Briggs John (2005). The use of Indegenous knowledge in Development: Problems and Challenges, Progress in Development Studies 5:99-114.

11. Chang'a LB, Yanda PZ \& Ngana J (1991). Indigenous knowledge in seasonal rainfall prediction in Selvanayagum M, Some of the traditional beliefs currently in vogue at Kovilpatti, Honey Bee,2(2).

12. Dhanapati D. L (1989\&1995). Folklore on the use of indidenous plants and animals in Manipur. 75-145.

13. Dhanapati, D. L. (1989). Ethnobiological studies of Manipur valley with reference to Museological Aspect .Ph.D. Thesis ,Manipur University.

14. Dekens Julie (2007).Local knowledge for disaster prepardness - A literature Review, (International Centre for Mountain Development : Kathmandu.

15. Dessai S, Lu X \& Risbey JS (2005). On the role of climate scenarios for adaptation planning, Global Environmental Change, Part A 15 (2): 87-97.

16. Fisher (1997). RJIF rain doesn, come: An Anthropological study of drought and Human Ecology in Western Rajasthan, Sydney Studies,Manohar Publishers and Distributors.

17. Galacgac ES \& Balisacan CM (2009). Traditional weather forecasting for sustainable agroforestry practices in Ilocos Norte Province, Phillippines, Forest Ecol Manage, 257 2044-205.

18. Laishram Imoba and Yurung Maipak Chothe (2003) Folksongs of Chothe, Lamlanghupi Women's Society.

19. Lantz TC \& Turner NJ (2003). Traditional phenological knowledge (TPK) of aboriginal peoples IN British Columbia, J Ethnobiol, 23(2) 263-286.

20. Hussain Z (1991).Human Adaptations in the Thar Desert, Geographical Review of India, J Indian Farming 53 (4):40-51.

21. India, C. o. (2001). Directorate of Census Operations,. Registrar General of India, Manipur .

22. Joshua S. Okanya \& Jurgen Kroschel (2013). Indigenous knowledge of seasonal weather forecasting: A case study in six regions of Uganda.

23. Lantz TC \& Turner NJ (2003). Traditional phenological knowledge (TPK) of aboriginal peoples IN British Columbia, J Ethnobiol, 23(2) 263-286.

24. Matari ER, Chang'a LB, Chikojo GE \& Hyera T (2008). Climate Change scenario development for Second National Communiction - Tanzania, TMA Res J, I 40-54.

25. Mcfarland JM \& Strand JF (1994). Weather-wise planning in farm management, In: Handbook of Agricultural Meteorology, edited by Groffiths JF, (Oxford University Press, London), 264-272.

26. Posey D (1992). Peoples of the fallow: a historical ecology on foraging in lowland South America. In: Redford, K.H., Padoch,C. (Eds.), Conservation of Neotropical Forests. Working fromTraditional Resource Use, Colombia University Press, New York, , 21-34. 
27. Ravi Shankar k, Pochaiah Maraty, Murthy VRK \& Ramakrishna YS (2008). In: Indigenous Rain Forecasting in Andhra Pradesh, edited by Prasad YG, (Central Research Institute for Dryland Agriculture, CRIDA, Santoshnagar, Hyderabad), 67.

28. Roncoli C,Ingram\& Kirshen P (2002). Reading the rains: Local knowledge and rainfall forecasting in Burkina Faso, Soc Nat Resour,15(2002)409-427.

29. Sen S (1992). Tribes and Castes of Manipur. 1st Edn,Mittal publications,New Delhi , 47-48.

30. Selvanayagun M (1991). Some of the traditional beliefs currently in vogue at Kovilpatti, Honey Bee, 2(2).

31. Sivanarayana G (1993). Indigenous Technical Knowledge and its Communication Pattern in East Godavari District of Andhra Pradesh, PhD Thesis, (Department of Extension Education,BHU, Varanasi).

32. State of Environment Report Manipur(2009). Environment and Ecological Office Government of Manipur ,Chapter 1:5.

33. Turner NJ (2003). The ethnobotany of 'edible seaweed'(Porphyra abbottiae Krishnamurthy and related species; Rhodophyta: Bangiales) and its use by first nations on the Pacific Coast of Canada, Can J Bot,81(2) :283-293.

34. Turner N J \& Clifton H (2006). The forest and the seaweed "Gitga'at seaweed ,Traditional Ecological Knowledge and community survival. In: Eating and Healing,edited by Pieroni A \& Price LL .

35. Turner NJ \& Clifton H (2009). "It's so different today": Climate change and indigenous life ways in British Columbia, Canada, Global Environ Change, 19:180-190.

36. Vavrova M, Gargosova HZ, Sucman E, Vecerek V, Korinek P, Zukal J, Zejda J, Sebastianova N, Kubistova I (2003). Game animals and small terrestrial mammals - suitable bioindicators for the pollution assessment in agrarian ecosystems. Fresen Environ Bull 12: 167-172.

37. VK A.D (2006). Traditional method of rainfall prediction through Almanacs in Ladakh. Indian Journal of Traditional Knowledge , 114-124. 